\title{
KEBIJAKAN PERJALANAN UDARA DI MASA PANDEMI CORONA VIRUS (COVID-19)
}

\author{
Yusti Fatmaningdyah", M. Fatchoelqorib ${ }^{2}$ \\ ${ }^{1,2}$ Sekolah Tinggi Penerbangan AVIASI, Jakarta, Indonesia
}

email : yusti.yufa@gmail.com, fatchoelq@gmail.com

\begin{abstract}
ABSTRAK
Industri penerbangan adalah salah satu industri yang besar dan melibatkan banyak sektor dalam perbaikannya baik secara nasional ataupun global. Penerbangan dunia sedang diuji dengan adanya pandemi corona virus. Di Indonesia, Kekuatan kebijakan pemerintah dalam perjalanan udara ini dilihat kefektifan penyelenggaraan kebijakannya. Berbagai peraturan perundang-undangan diterbitkan guna menstabilkan dan mencegah penyebaran Corona virus secara lebih luas. Namun pada kenyataannya masih terdapat banyak kendala yang dihadapi kebijakan sehingga menimbulkan banyak dampak baik secara nasional maupun internasional. Indonesia menghadapi berbagi masalah dimulai dari dampak Penurunan kebutuhan akan transportasi udara dan pengurangan jadwal penerbangan atas kebijakan pemerintah yang mengakibatkan menurunnya pemasukan airlanes yang menggangu sirkulasi ekonomi maskapai penerbangan. Artikel ini dibuat secara kualitatif dengan pengumpulan data study literatur yang dapat menggambarkan keadaan kebijakan perjalanan udara di Indonesia. Hasil lainnya syarat yang dibutuhkan penumpang yang berbeda untuk setiap bandara di daerah bergantung pada zona penyebaran corona virus, membuat kebingungan masyarakat yang ingin melakukan perjalanan udara, karena kurangnya sosialisasi syarat penerbangan yang dilakukan. Untuk itulah penting untuk mengkaji lebih dalam untuk dapat menentukan kebijakan apa yang terbaik dilakukan dengan tidak merugikan baik penumpang ataupun perusahaan penerbangan di Indonesia.

Kata kunci : aviasi, kebijakan, regulasi, pendapatan airlanes, persyaratan penerbangan
\end{abstract}




\section{PENDAHULUAN}

Industri penerbangan dimulai pada tahun 1946 oleh Tentara Republik Indonesia Angkatan Udara (TRI AU). Tahun 1964, Indonesia memiliki dua perusahaan penerbangan berstatus Badan Usaha Milik Negara, yaitu Garuda Indonesia dan Merpati Nusantara Airlines, sedangkan dua perusahaan penerbangan swasta, yaitu Mandala Airlines dan Bouraq Airlines (Indonesia National Air Carriers Association, 2019). Industri penerbangan terus berkembang dan semakin banyak perusahaan penerbangan terlahir di Indonesia sampai dengan saat ini. Namun dimulai pada akhir tahun 2019 sampai dengan akhir tahun 2020, merebaknya pandemi yang merupakan salah satu jenis penyakit dari virus bernama corona. Corona virus adalah suatu kelompok virus yang menyebabkan infeksi saluran nafas pada manusia mulai dari batuk pilek hingga lebih serius seperti jenis virus terbaru ini yaitu COVID-19 (World Health Organization Indonesia, 2020). Orang dapat tertular virus ini dari orang lain melalui percikan-percikan dari hidung atau mulut yang keluar saat orang yang terinfeksi COVID-19 batuk, bersin atau berbicara. Percikan tersebut relatif berat, perjalanannya tidak jauh dan jatuh ketanah dengan cepat, oleh karena itu orang dapat terinfeksi virus tersebut jika mengirup percikan dari orang yang terinfeksi. Virus ini sejak awal 2020 sudah memasuki wilayah
Indonesia dan Indonesia penerapan physical distancing dalam mengawali aturan kesehatan yang berlaku dimasyarakat, dilanjutkan dengan social distancing atau di Indonesia lebih dikenal dengan Pembatasan Sosial Berskala Besar (PSBB), kemudian masuk kepada kebijakan PSBB Transisi, lalu kebijakan new normal, dan saat ini kembali ke kebijakan PSBB Transisi karena melihat penambahan yang signifikan di Indonesia.

Data pada awal Juli 2020 di Indonesia tercatat jumlah 63.749 orang terkontaminasi covid-19, 31.473 orang masih dalam perawatan 3.171 orang meninggal dunia. Terdapat data Orang Dalam Pemantauan (ODP) sejumlah 39.928 orang dan Pasien Dalam Pengawasan (PDP) 13.763 orang (Gugus Tugas Percepatan Penanganan Covid 19, 2020). Pemaparan data tersebut memperlihatkan bahwa Indonesia masih belum aman dan belum stabil menghadapi pandemik ini. Gambar 1.1 memperlihatkan pergerakan data status kasus terkontaminasi mulai pertengahan bulan Juni sampai dengan awal bulan Juli 2020. Kasus terkontaminasi pergerakannya sempat menurun pada akhir bulan Juni 2020, namun kembali meningkat pada awal bulan Juli 2020 memasuki era baru yang disebut new normal.

Gambar 1.1 Data Nasional Kasus terkontaminasi positif covid-19 Per-hari (status kasus 5 Juli 2020) 


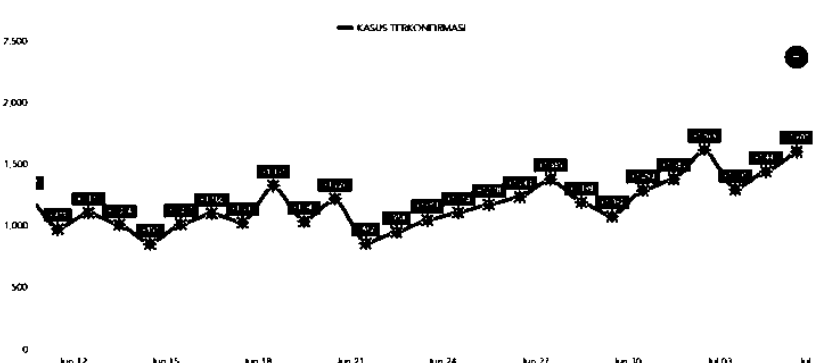

Sumber: (Gugus Tugas Percepatan Penanganan Covid 19, 2020), Tim Khusus Gugus Tugas Percepatan Penanganan Covid-19, 6 July 2020

Pada Juli 2020, Kementerian Kesehatan menerbitkan Keputusan Menteri Nomor HK.01.07.Menkes/413/2020 tentang Pedoman Pencegahan dan Pengendalian Corona virus Desease pada Juli 2020 dengan perubahan klasifikasi istilah pada pasien Covid-19 yaitu kasus suspek, kasus probable, kontak erat dan kasus konfirmasi. Tercatat pada pertengahan November 2020, kasus positif adalah sebesar 470.648 meningkat lebih dari 410 ribu orang sejak Juli 2020, sebagaimana gambar 1.2

Gambar 1.2. Data Sebaran Kasus Covid 19 (Global \& Indonesia)

Global
Negara
220
Terkonfirmasi
62363527
Meninggal
1456687

Last update: 30 November 2020, 09:37 pm GMT+7 I Sumber: WHO

Sumber: (Gugus Tugas Percepatan Penanganan Covid 19, 2020)

Sejak diterapkannya PSBB, PSBB Transisi, sampai dengan kebijakan new normal yang kemudian saat ini berubah menjadi PSBB Transisi, diberlakukan juga pembatasan kegiatan ekonomi, industri, bahkan transportasi. Pembatasan juga berlaku pada perjalanan baik darat, laut, maupun udara. Secara nasional, Jakarta sebagai ibu kota negara melakukan pembatasan transportasi darat terlebih dahulu yang dilanjutkan dengan pembatasan transportasi udara, kemudian diikuti oleh provinsi lain yang memiliki fasilitas transportasi udara. Jika secara internasional pembatasan perjalanan udara dilakukan pada bulan April 2020. Aturan-aturan yang mendorong social distancing dibuat terutama pada transportasi udara demi terwujudnya Pembatasan Sosial Berskala Besar yang efektif bagi masyarakat. Namun hal ini berimbas kepada beberapa sektor terutama yang berhubungan dengan industri penerbangan. Mengacu pada Data Badan Pusat Statistik (BPS) Agustus 2020, jumlah penumpang penerbangan domestik hanya mencapai 1,99 juta penumpang, dibandingkan pada bulan Juli 2020 yang meningkat 36,23 persen dari 1,46 juta penumpang. Namun jika dibandingkan dengan kondisi normal pada Agustus 2019, jumlah penumpang domestik dapat mencapai 6,72 juta penumpang, kondisi anjloknya jumlah penumpang sebanyak 70,43 persen ini menyebabkan pengaruh besar terhadap industri penerbangan di Indonesia (Ramli, 2020). 
Pada artikel ini akan dijelaskan kebijakan-kebijakan apa saja yang telah dibuat pemerintah untuk perjalanan udara dan mempengaruhi sektor penerbangan di Indonesia sektor penerbangan apa saja yang terpengaruh kebijakan pandemi.

\section{LANDASAN TEORI}

Teori yang digunakan dalam pembahasan ini adalah mengenai teori kebijakan publik. Penulis menggunakan teori kebijakan publik sebagai ladasan untuk melihat proses pembuatan kebijakan dan penerapan kebijakan yang dilakukan oleh pemerintah pada masa pandemi khususnya untuk kebijakan perjalanan udara. Analisis kebijakan menggabungkan lima prosedur yang lazim dipakai dalam pemecahan masalah manusia: yang pertama perumusan masalah (defenisi) yang menghasilkan informasi mengenai kondisi-kondisi yang menimbulkan masalah kebijakan; lalu Peramalan (prediksi) menyediakan informasi mengenai konsekuensi di masa mendatang dari penerapan alternative kebijakan termasuk tidak melakukan sesuatu; kemudian Rekomendasi (preskripsi) menyediakan informasi mengenai nilai atau masalah; Pemantauan (deskripsi) menghasilkan informasi tentang konsekuensi sekarang dan masa lalu dari diterapkannya alternative kebijakan, dan yang terakhir adalah evaluasi yang menyediakan informasi mengenai nilai atau kegunaan dari konsekuensi pemecahan atau pengatasan masalah. (Dunn, 2003). Proses analisis kebijakan adalah serangkaian aktivitas intelektual yang dilakukan dalam proses kegiatan yang pada dasarnya bersifat politis. Aktivitas politis tersebut dijelaskan sebagai proses pembuatan kebijakan dan divisualisasikan sebagai serangkaian tahapan yang saling bergantung dengan tahapan: penyusunan agenda, formulasi kebijakan, adopsi kebijakan, implementasi kebijakan dan penilaian kebijakan (Dunn, 2003).

Pada dasarnya dalam memahami kebijakan publik, terdapat dua jenis aliran atau pemahaman, yaitu (Nugroho, 2017):

1. Kontinentalis, yang cenderung melihat bahwa kebijakan adalah turunan dari Hukum, bahkan kadang mempersamakan antara kebijakan publik dan hukum, utamanya hukum publik, ataupun hukum tata negara, sehingga melihat sebagai proses interaksi di antara institusi-institusi negara.

2. Anglo-Saxonis, yang cenderung memahami bahwa kebijakan publik adalah turunan dari Politik-demokrasi, sehingga melihatnya sebagai sebuah produk interaksi antara negara dan publik.

Penulis pada artikel ini akan melihat dari formulasi kebijakan, adopsi kebijakan dan implementasi kebijakan yang mana 
pejabat merumuskan alternative kebijakan untuk mengatasi masalah guna melihat perlunya membuat perintah eksekutif atau tindakan legislatif dengan menggunakan kebijakan yang diadopsi dari kebijakan lainnya sehingga kebijakan tersebut dapat dilaksanakan oleh unit-unit terkait. Dalam kasus ini kebijakan yang dibuat oleh pemerintah khususnya Kementerian Perhubungan bersama dengan Kementerian Kesehatan dan Satgas Covid-19 dalam merancang kebijakan perjalanan penerbangan yang berdampak pada industri penerbangan.

\section{METODE PENELITIAN}

Pembahasan tentang kebijakan perjalanan penerbangan pada masa pandemi Covid-19 menggunakan metode kualitatif dengan model pengumpulan data penelitian berupa studi dokumen (Literature Study). Data-data dan artikel-artikel yang didapat kemudian diolah, dibaca dan diperiksa oleh peneliti secara hati-hati, sehingga dapat membentuk sebuah gambaran analisa yang jelas. Data-data untuk penelitian ini didapat dari beberapa instansi penerbangan di Indonesia, baik instansi pemerintah ataupun asosiasi-asosiasi penerbangan nasional dan internasional selain itu sumber lainnya berupa artikel-artikel yang dari media daring Indonesia.

\section{PEMBAHASAN}

Penerbangan merupakan salah satu industri global yang mempekerjakan jutaan orang dan menjadi penopang puluhan juta lainnya, serta menjadi pusat saraf bisnis dan wisata nasional serta internasional. Akibat yang ditimbulkan dari perkembangan pandemik Corona virus ini adalah sekitar 17.000 pesawat diparkir di berbagai bandara di seluruh dunia. Penerbangan harian pun turun sekitar $80 \%$ sejak awal tahun, bahkan di beberapa kawasan terdapat penghentian pengoperasian bandar udara (Leggett, 2020).

Jumlah bandara yang tercatat di Indonesia adalah 332, data ini termasuk dengan bandara yang dikelola oleh Angkasa pura 1 (15 Bandara) dan Angkasa pura 2 (19 Bandara). Bandara-bandara yang ada di Indonesia bukan hanya bandara yang dikelola oleh pemerintah pusat saja namun juga terdapat bandara yang dikelola kementerian ataupun swasta. Pandemi ini sangat mempengaruhi bandara-bandara besar yang melayani penerbangan terjadwal dengan menggunakan pesawat jenis Jet Narrow Body dan Wide Body yang mengangkut penumpang, namun tidak mempengaruhi pengangkutan kargo karena tidak ada pembatasan atas hal tersebut.

Maskapai penerbangan dan operator bandara terdampak serius akibat pandemik corona virus. Berkurangnya frekuensi penerbangan terjadwal atau scheduled flight secara drastis tanpa kejelasan waktu 
mengakibatkan banyak kru pesawat dirumahkan. Pemotongan gaji hingga Pemutusan Hubungan Kerja tampil sebagai opsi dan hal ini juga merupakan fenomena global yang juga menimpa maskapai internasional dan nasional. British Airways (BA), perusahaan pemilik International Airlines Group (IAG) mengumumkan bahwa mereka akan memotong 12.000 pos dari jumlah total karyawan 42.000 orang. IAG memperkirakan selama beberapa tahun ke depan, penumpang BA tidak akan kembali lagi ke jumlah penumpang seperti tahun 2019. Sementara Easy Jet (maskapai bertarif rendah di Inggris) telah merumahkan 4.000 karyawannya di Inggris. Qantas (maskapai Australia) juga merumahkan 20.000 karyawan, sebanyak 700 pilot American Airlines sepakat untuk pensiun dini (Leggett, 2020). Garuda Indonesia, perusahaan penerbangan plat merah Indonesia juga tidak luput dari permasalahan ini. Sebanyak 135 pilot dipercepat masa kontraknya dan sebanyak 800 karyawan dengan status Pegawai Perjanjian Kerja Waktu tertentu (PKWT) dirumahkan sejak 14 Mei 2020 (Pratama, 2020). Air Asia, menghentikan sementara layanan penerbangannya di Indonesia mulai bulan April 2020, sebanyak 96 persen pesawat mereka tidak beroperasi sehingga tidak ada pemasukan, oleh karena itu perusahaan memangkas gaji karyawan 15-75 persen (Annur, 2020). Kontras dengan keterangan sebelumnya, dua operator bandara nasional di Indonesia yakni Angkasa Pura I dan Angkasa pura II menyatakan tidak ada pemotongan gaji maupun PHK bagi karyawannya (Nugraha, n.d.).

\section{International Air Transport} Association (IATA) memprediksi kuartal ketiga tahun ini menjadi tolak awal pemulihan penerbangan domestik dengan catatan situasi kondusif, namun pemulihan penerbangan internasional diperkirakan memerlukan waktu lebih lama. Tantangan yang dihadapi ketika memasuki masa pemulihan adalah arus kas (cashflow) maskapai, permintaan pengembalian dana (refund) tiket pesawat yang tinggi berpotensi mengganggu strategi pemulihan. IATA lebih menyarankan untuk penggantian jadwal (reschedule) dibandingkan pembatasan penerbangan yang berujung pada refund agar upaya maskapai kembali pulih tidak berhadapan dengan kendala tersebut (Nugraha, n.d.).

Direktorat Jenderal Perhubungan Udara, Kementerian Perhubungan memaparkan dampak pandemi corona virus pada transportasi udara antara lain; pengurangan jadwal penerbangan, penurunan kebutuhan, aspek ekonomi dan penurunan pendapatan. Pengurangan jadwal penerbangan terindentifikasi menurun sampai dengan $80 \%$ termasuk di dalamnya penerbangan domestik dan internasional. Penurunan kebutuhan juga teridentifikasi 
akibat pencanangan PSBB Transisi pada beberapa daerah yang memiliki transportasi udara. Secara signifikan mempengaruhi ekonomi dan sumber devisa negara. Penurunan pendapatan terjadi baik pada maskapai penerbangan dan bandara serta sektor terkait lainnya menghadapi potensi penurunan pendapatan (Alwi, 2020). Dampak-dampak yang terjadi pada industri penerbangan penting untuk dikaji lebih serius dan penting adanya kolaborasi industri penerbangan dalam rangka mengembalikan sektor industri penerbangan ke tingkat normal.

Indonesia memiliki Undang - Undang Nomor 1 Tahun 2009 tentang Penerbangan, sebagai dasar pengelolaan industri penerbangan. Melihat kondisi saat ini, pemerintah khususnya Kementerian Perhubungan membuat kebijakan-kebijakan yang dibutuhkan untuk mendukung usaha nasional dalam rangka menekan penyebaran corona virus. Kementerian Perhubungan menerbitkan Peraturan Menteri Nomor PM 18 Tahun 2020 tentang Pengendalian Transportasi dalam rangka pencegahan penyebaran Corona Virus 2019 (COVID-19). Peraturan tersebut berdasar pada Peraturan Pemerintah Nomor 21 Tahun 2020 tentang Pembatasan sosial Berskala Besar dalam Rangka Percepatan Penanganan Corona Virus 2019 (COVID-19) dan Peraturan Menteri Kesehatan Nomor 9 Tahun 2020 tentang
Pedoman Pembatasan Sosial Berskala Besar dalam Rangka Percepatan Penanganan Corona Virus 2019 (COVID-19). Alasan Kementerian Perhubungan membuat peraturan Menteri yang berdasar pada peraturan pemerintah karena pandemi corona virus ini merupakan kejadian luar biasa nasional dan sangat terkait dengan kesehatan, untuk itulah peraturan Menteri Kesehatan juga dijadikan sebagai rujukan. Transportasi merupakan salah satu sektor yang memiliki resiko penyebaran tinggi karena interaksi manusia yang intens terjadi dalam angkutan transportasi terutama transportasi umum. Seperti yang telah disinggung dalam bagian pendahuluan bahwa corona virus adalah virus yang mudah sekali menyebar lewat interaksi manusia. Terutama pada angkutan tranportasi dengan model tertutup total seperti pesawat terbang.

Selain kedua Peraturan yang menjadi dasar tersebut, Gugus Tugas Percepatan Penanganan Covid-19 juga membuat Surat Edaran Gugus Tugas Percepatan Penanganan Covid-19 Nomor 7 Tahun 2020 tentang Kriteria dan Persyaratan Perjalanan Orang dalam Masa Adaptasi Kebiasaan Baru Menuju Masyarakat Produktif dan Aman Corona Virus 2019 (Covid-19). Surat Edaran ini dikhususkan untuk masyarakat yang akan melakukan perjalanan baik darat, laut maupun Udara. Kemudian surat edaran ini juga menjadi rujukan Kementerian Perhubungan 
membuat kebijakan terkait transportasi darat, laut dan udara termasuk dengan protokol yang harus dilakukan.

Peraturan Menteri Perhubungan Nomor 18 Tahun 2020 yang diterbitkan pada 9 April 2020 mengatur berbagai hal terkait penjagaan keamanan baik dari penumpang, operator sarana transportasi dan operator prasarana transportasi transit. Terkhusus untuk perjalanan udara, peraturan ini lebih mengatur dari segi keamanan kesehatan, terdapat empat pasal dalam peraturan kebijakan ini yang membedakan moda perjalanan udara dengan moda perjalanan lainnya dan 1 pasal yang penting untuk diketahui. Pertama pada pasal 6 huruf (h) menjelaskan bahwa untuk trasnportasi udara memastikan seluruh penumpang mengenakan masker selama penerbangan dan mengingatkan terkait pengisian kartu kewaspadaan kesehatan / kartu kuning (Health Alert Card/HAC). Penumpang saat dalam lingkungan penerbangan baik saat Pre-Flight, In-Flight dan Post-Flight wajib menggunakan masker bahkan saat ini bisa juga ditambahkan Face shield / pelindung muka, hal ini untuk mencegah kemungkinan percikan-percikan air liur dari penumpang lainnya yang memiliki resiko terpapar atau Orang Tanpa Gejala (OTG). Kartu kewaspadaan kesehatan penting diisi untuk pemantauan penumpang oleh pihak operator sarana transportasi. Di Indonesia kartu kewaspadaan kesehatan dapat dilakukan secara online dengan mengunduh aplikasi kartu kewaspadaan kesehatan pada Google Play atau IOS.

Pasal 8 ayat 2 huruf (f), pada pasal ini dijelaskan bahwa operator sarana transportasi memiliki kewajiban untuk memastikan personil ground handling pada transportasi udara menggunakan masker dan sarung tangan. Ground handling adalah pelayanan atau penanganan di darat (pre-flight dan postflight service) (Atmadjati, 2014), unit-unit yang bekerjasama dalamnya secara operasional yaitu passenger handling, aircraft handling, in-flight service dan cargo handling. Pentingnya personil ini menggunakan masker dan sarung tangan, karena mereka adalah para pegawai yang berhubungan langsung dengan penumpang, barang penumpang dan juga pesawat yang pernah dan akan ditumpangi oleh penumpang. Kemudian pasal 14, pasal ini yang paling mempengaruhi industri penerbangan karena sehubungan dengan pasal 10 tentang pengendalian transportasi penumpang, maka pengendalian transportasi udara meliputi;

a. Pengurangan kapasitas / jumlah penerbangan (Slot Time) bandara udara berdasarkan evaluasi. Maksudnya adalah karena waktu pengoperasian bandara yang dipersingkat dalam sehari sehingga jumlah penerbangan pun juga harus dikurangi. 
b. Pembatasan jumlah penumpang paling banyak 50 persen dari jumlah kapasitas tempat duduk dengan penerapan jaga jarak fisik (physical distancing). Hal ini menambah resiko kerugian bagi perusahaan penerbangan.

c. Penyesuaian tarif batas atas dan/atau pemberlakuan tuslah / surcharge berdasarkan ketentuan peraturan perundang-undangan. Nilai ini membuat kemungkinan tiket pesawat akan jauh semakin mahal dan akan lebih sulit menarik penumpang.

Pasal selanjutnya adalah pasal 18 , pasal ini cukup melegakan karena adanya kelonggaran yang diberikan oleh Kementerian Perhubungan dimana pesawat konfigurasi penumpang dapat digunakan untuk mengangkut kargo didalam kabin penumpang (passenger compartment) khusus untuk pengangkutan kebutuhan medis, kesehatan dan sanitasi pangan. Pada Peraturan Menteri ini juga terdapat lampiran yang berisikan petunjuk pelaksanaan mudik dengan berbagai moda transportasi yang ada.

Perubahan untuk Peraturan Menteri ini ditetapkan pada tanggal 8 Juni 2020, dimana berisikan beberapa perubahan khususnya pada pasal 14 tentang pengendalian kegiatan transportasi yang sebelumnya pembatasan slot time menjadi penyesuaian slot time bandar udara berdasarkan evaluasi dan juga perubahan jumlah penumpang yang sebelumnya hanya boleh 50 persen dari jumlah kapasitas penumpang menjadi pembatasan jumlah penumpang dari kapasitas tempat duduk dengan penerapan jaga jarak fisik (Physical distancing). Selain itu pada peraturan Menteri ini juga mempertegas sanksi yang diberikan jika terdapat pelanggaran yang sebelumnya belum terdapat pada peraturan Menteri sebelumnya.

Pembahasan selanjutnya adalah Surat Edaran yang diterbitkan oleh Gugus Tugas Covid-19, Surat Edaran Nomor 7 Tahun 2020 tentang Kriteria dan Persyaratan Perjalanan Orang dalam Masa Adaptasi Kebiasaan Baru Menuju Masyarakat Produktif dan Aman Corona Virus 2019 (Covid-19) yang ditetapkan pada 6 Juni 2020, bagian khusus tentang transportasi udara yang penting untuk diketahui terutama bagi penumpang moda transportasi udara adalah pada pasal $\mathrm{F}$ ayat 2, huruf (b). Pada pasal tersebut berisikan ketentuan bahwa setiap individu yang melakukan perjalanan orang dengan transportasi umum udara diwajibkan untuk menunjukan identitas diri, kemudian menunjukkan surat keterangan Uji Tes Polymerase Chain Reaction (PCR) dengan hasil negatif yang berlaku 7 hari atau surat keterangan uji rapid-test dengan hasil non reaktif yang berlaku 3 hari pada saat keberangkatan, syarat lainnya adalah menunjukan surat keterangan bebas gejala 
seperti influensa (Influenza-illness) yang dikeluarkan oleh dokter Rumah Sakit/Puskesmas bagi daerah yang tidak memiliki fasilitas tes PCR dan/atau Rapidtest. Namun kemudian pasal ini terdapat perubahan pada Surat Edaran Gugus Tugas selanjutnya Nomor 9 Tahun 2020 tentang Perubahan atas Surat Edaran Nomor 7 Tahun 2020 tentang Kriteria dan Persyaratan Perjalanan Orang dalam Masa Adaptasi Kebiasaan Baru Menuju Masyarakat Produktif dan Aman Corona Virus 2019 (Covid-19), perubahan terjadi pada nilai ke 2 tentang keberlakuan surat keterangan Polymerase Chain Reaction (PCR) dan Rapid test. Huruf (b) angka (2) berubah menjadi menunjukan Surat Keterangan Uji Tes PCR dengan hasil negatif atau Surat Keterangan Uji Rapid-Test dengan hasil non-reaktif yang keduanya berlaku 14 hari pada saat keberangkatan.

Peraturan kebijakan lainnya yang dikeluarkan oleh Kementerian Perhubungan, khususnya Direktorat Jenderal Transportasi Udara adalah adanya Surat Edaran Nomor SE 13 Tahun 2020 tentang Operasional Transportasi Udara dalam Masa Kegiatan Masyarakat Produktif dan Aman dari Corona Virus 2019 (Covid-19). Surat Edaran ini ditetapkan pada tanggal 8 Juni 2020, yaitu dua hari setelah penetapan Surat Edaran Gugus Tugas Nomor 7 Tahun 2020. Peraturan kebijakan ini berisikan panduan operator penerbangan, penanganan penumpang pesawat udara angkutan udara dan pengaturan slot time dalam rangka pencegahan penyebaran Corona Virus 2019 (Covid-19). Aturan operasional terperinci dijelaskan dalam peraturan tersebut agar aturan yang berlaku pada setiap operator bandara seragam dan sesuai standar Internasional yaitu dari International Civil Aviation Organization (ICAO). ICAO adalah organisasi Perserikatan Bangsa-Bangsa yang mengkhususkan kegiatannya pada bidang penerbangan. Organisasi ini bekerjasama dengan industri penerbangan global mengembangkan Standards and Recommended Practices (SARP's), SARP's adalah standar dan rekomendasi prosedur untuk pelaksanaan kegiatan penerbangan, sehingga seragam di seluruh dunia. Saat ini sudah terdapat 1000 SARP's yang disebut dengan Annex, untuk kasus pandemi corona virus ini, SARP's yang dipergunakan adalah Annex 9 tentang Facilitation.

Pembaharuan peraturan kebijakan penerbangan yang dilakukan pada 30 November 2020, untuk penerbangan kawasan domestik memiliki perbedaan persyaratan dan dokumen penerbangan bergantung pada kota tujuan penerbangan domestik yang akan dikunjungi. Tujuan Denpasar, Labuan Bajo, Ambon, Timika, Merauke dan tujuan kota akhir lainnya dapat menggunakan dokumen hasil Rapid-Test (Non-Reaktif) atau Swab 
$P C R$ (Negatif) yang disertai dengan penambahan persyaratan dari masing-masing pemerintah daerah setempat (Garuda indonesia Airlines, 2020). Contohnya untuk wilayah Denpasar seluruh penumpang tujuan Denpasar wajib mendaftarkan dirinya melalui portal

LoveBali

(https://lovebali.baliprov.go.id/register);

Kemudian untuk wilayah tujuan

Labuan Bajo, penumpang diwajibkan untuk dapat mendaftarkan dirinya pada laman portal registrasi pemerintah daerah https://registration.labuanbajoflores.id/ .

Lain hal dengan beberapa daerah tujuan yang disebutkan sebelumnya, untuk wilayah tujuan Jayapura, Sorong dan Nabire, Penumpang diwajibkan untuk memiliki dokumen kesehatan berupa surat kesehatan dengan hasil Tes Swab PCR (negatif) dilengkapi dengan beberapa dokumen lainnya bergantung pada pemerintah daerah masingmasing (Garuda indonesia Airlines, 2020).

Banyak hal yang bisa didiskusikan dari pembahasan sebelumnya, jika dilihat dari sisi model kebijakan yang dibuat formulasi kebijakan yang memang telah membuat beberapa alternatif dan mengadopsi dari kebijakan lainnya. Namun kebijakan yang ada cenderung kepada arah kontinentalis (Nugroho, 2017). Kebijakan cenderung melihat bahwa kebijakan publik adalah turunan dari hukum, yang lebih spesifik terlihat lagi adalah ketidaklengkapan sebuah kebijakan utama, sehingga dibutuhkan kebijakan-kebijakan pendamping untuk melengkapi. Hal tersebut terjadi pada kebijakan yang dibuat oleh Kementerian Perhubungan. Kebijakan yang dibuat cenderung hanya bersifat tata laksana semata yang tidak menyangkut semua aturan sehingga diperlukan aturan turunan guna memperjelas aturan utamanya. Sebaiknya aturan kebijakan dibuat cukup satu yang meliputi seluruh bagian dan sifatnya terperinci, selain itu perubahan-perubahan kebijakan satu perubahan kebijakan selanjutnya yang terjadi dalam waktu singkat mengakibatkan adanya kebingungan masyarakat mengenai syarat penumpang pengguna moda transportasi udara. Sesuai aturan umum syarat yang diperlukan hanya kartu tanda penduduk, surat keterangan PCR atau Rapid-test atau surat keterangan puskesmas atau surat keterangan rumah sakit bebas influensa, namun pada kenyataannya keberlakuan dibeberapa daerah berbeda. Hal ini menyebabkan implementasi kebijakan setiap unit berbeda-beda dan menimbulkan kesulitan bagi masyarakat.

Salah satu contoh kasus penerbangan dari Ternate ke Jakarta, transit Manado, dua orang ini melakukan penerbangan dengan lancar dari Ternate ke Manado hanya dengan surat keterangan rapid-test, namun saat akan melanjutkan penerbangan ke Jakarta mereka terkendala dengan tidak adanya surat dari 
kelurahan dan Surat Keterangan Izin Masuk (SKIM) DKI Jakarta (Sabu, 2020). Perbedaan penerapan persyaratan pada daerah zona merah virus corona seharusnya disosialisasikan lebih jelas di bandara keberangkatan mana saja daerah-daerah yang memiliki persyaratan khusus lain di luar persyaratan umum yang ditentukan pemerintah pusat, sehingga tidak terjadi kasus serupa yang menimbulkan kekecewaan penumpang.

Permasalahan lainnya yang menjadi perhatian adalah harga tes PCR yang biayanya lebih besar dibandingkan dengan biaya tiket pesawat. Beberapa bandara di Indonesia khususnya bandara Internasional mensyaratkan menggunakan Surat Keterangan PCR (khusus Jabodetabek salah satunya) dan Rapid-test yang harganya lebih mahal dari batas atas biaya tiket pesawat yang dibeli (untuk test PCR dan setengah biaya pesawat untuk Rapid-test), hal ini membuat penumpang berpikir dua kali untuk menggunakan moda transportasi udara, yang mengakibatkan penurunan jumlah penumpang dan industri penerbangan semakin terpuruk. Beberapa kebijakan untuk transportasi, terutama transportasi udara tidak dibarengi dengan kesiapan bidang lainnya untuk menopang kebutuhan tersebut. Beberapa bandara telah menyediakan layanan Rapid-test namun Rapid-test yang disediakan tersebut sangat lamban dan tidak sesuai dengan brosur yang dibagikan sebelumnya, dalam brosur dijanjikan 30 menit hasil tes selesai kenyataannya butuh waktu 2 jam, sehingga terdapat penumpang yang gagal berangkat (Firmansyah, 2020).

Mengembalikan industri penerbangan ke kondisi normal tidaklah mudah, sampai saat ini, pemerintah masih fokus pada kebijakan yang berhubungan dengan kesehatan, sedangkan dampak ekonomi, khususnya industri penerbangan, terpampang nyata dan tidak terelakkan dengan banyaknya jumlah pegawai yang kehilangan pekerjaannya dikarenakan pemasukan perusahaan yang berkurang. Penting bagi pemerintah terkhusus instansi terkait dengan industri penerbangan mengkaji lebih dalam hal-hal yang perlu diperbaiki dalam kebijakan yang telah dibuat. Contohnya untuk PCR atau Rapid-test yang merupakan syarat mutlak untuk menggunakan moda transportasi udara, bisa di diskusikan dengan kementerian kesehatan untuk mengadaan atau supply yang lebih murah dan perbaikan pelayanan dibandara untuk rapid-test agar sesuai dengan brosur yang dibagikan kepada penumpang.

Selanjutnya pemerintah juga harus membantu industri penerbangan melakukan sosialisasi kepada masyarakat bahwa menggunakan moda transportasi udara adalah moda yang aman bagi masyarakat untuk bepergian. Hal ini karena pesawat-pesawat yang ada saat ini telah menggunakan sistem 
penyaringan partikel udara yang kuat atau High Efficiency Particulate Air (HEPA), dimana adanya udara segar yang dicampur dengan udara re-sirkulasi melalui sistem filterasi yang telah disebutkan sebelumnya (Ramli, https://money.kompas.com, 2020). Sehingga walaupun pesawat merupakan moda transportasi tertutup, namun tetap aman dan nyaman bagi penumpang. Adanya HEPA juga tidak boleh melonggarkan protokol kesehatan yang ada, para penumpang juga tetap wajib menggunakan masker selama di dalam pesawat dan pihak maskapai juga tetap harus melakukan disinfektan untuk seluruh bagian kabin yang berinteraksi dengan penumpang.

\section{KESIMPULAN}

Kesimpulan yang didapat adalah kebijakan untuk perjalanan udara masih memerlukan banyak perbaikan dan kajian yang mendalam. Kebijakan-kebijakan yang dibuat seharusnya selaras dengan kebutuhan masyarakat sebagai penumpang pengguna moda transportasi udara. Keselarasan dengan instansi lainnya untuk mendukung pelayanan prima pada transportasi udara juga masih harus diperbaiki dan lebih ditingkatkan. Penentuan kebijakan yang dibuat nantinya harus dapat menguntungkan semua pihak baik dari pihak penumpang ataupun pihak perusahaan penerbangan, sehingga akan terwujud industri penerbangan Indonesia yang kembali normal dan menguntungkan semua pihak.

\section{DAFTAR PUSTAKA}

Alwi, M. (2020). Pengaruh Pandemi Covid-19 pada keamanan penerbangan; tantangan dan peluang manuju New Normal. The Impact of Covid-19 to the Aviation Security; Challenges and opportunities to the New Normal. Jakarta: CSAS.

Annur, $\quad$ S. $\quad$ M. (2020, 4 12). https://katadata.co.id/berita/2020/04/ 12/96-pesawatnya-tak-beroperasiairasia-potong-gaji-seluruhkaryawan. Retrieved from www.katadata.com.

Atmadjati, A. (2014). Manajemen Operasional Bandar Udara. Yogyakarta, Yogyakarta, Indonesia: Deepublish.

Dunn, W. N. (2003). Pengantar Analiais Kebijakan Publik (Translated edition). Yogyakarta: Gadjah Mada University Press.

Firmansyah. (2020, $06 \quad$ 29). https://regional.kompas.com/read/20 20/06/29/16451701/penumpang-lionair-gagal-berangkat-akibat-rapidtest-lamban?page=all.$\quad$ Retrieved from kompas.com.

Garuda indonesia Airlanes. (2020, November $30)$. https://www.garuda- 
indonesia.com/id/id/news-and-events.

Retrieved from https://www.garudaindonesia.com: https://www.garudaindonesia.com/id/id/news-and-

events/kebijakan-operasional-terkaitcovid19

Gugus Tugas Percepatan Penanganan Covid $19 . \quad$ (2020, Juli). https://covid19.go.id/peta-sebaran. Retrieved from Covid19.go.id.

Indonesia National Air Carriers Association. (2019, April). http://inaca.or.id/wpcontent/uploads/2019/11/buku-

Sejarah-INACA_cetak-2-Okt-finalrev_compressed.pdf. Retrieved from www.inaca.or.id.

Leggett, T. (2020, May 8). https://www.bbc.com/indonesia/dunia -52577423. Retrieved from www.bbc.com.

Nugraha, R. A. (n.d.). Retrieved from https://katadata.co.id/opini/2020/05/0 2/kalutnya-dunia-penerbangannasional-di-tengah.

Nugroho, R. (2017). Public Policy. Jakarta, DKI Jakarta: PT Elex Media Komputindo.

Pratama, A. M. (2020, 6 5). https://money.kompas.com/read/2020 106/05/140000726/dirut-garuda-135pilot-garuda-bukan-di-phk-tapidipercepat-masa-kontrak. Retrieved from www.kompas.com.
Ramli, R. R. (2020, 10 4). https://money.kompas.com. Retrieved from www.kompas.com: https://money.kompas.com/read/2020 /10/04/152033326/jumlahpenumpang-pesawat-masih-jauh-dibawah-level-normal.

Ramli, R. R. (2020, July 7). https://money.kompas.com. Retrieved from www.kompas.com: https://money.kompas.com/read/2020 /07/07/200100026/bos-garuda-yakinsirkulasi-udara-di-pesawat-cegahpenularan-covid-19

Sabu, S. (2020, Mei 11). https://news.okezone.com/read/2020/ 05/11/340/2212523/ditolakberangkat-calon-penumpang-inimarah-marah-di-bandara-samratulangi. Retrieved from News. Okezone.com.

World Health Organization Indonesia. (2020, July).https://www.who.int/indonesia/n ews/novel-coronavirus/qa-for-public. Retrieved from https://www.who.int. 